\title{
INTERNATIONALIZING HIGHER EDUCATION OF UKRAINE: NATIONAL POLICY
}

\section{Mariia Debych ${ }^{1}$}

DOI: https://doi.org/10.30525/978-9934-26-049-0-18

Abstract. Internationalization has become a subject of global interest and global geographical coverage. In order to develop a National Internationalization Strategy of Ukraine, it is necessary to take into account trends and patterns in the global market of international education services. The aim of this article is to examine national policy of Ukraine for higher education internationalization, consider issues of foreign students' study in Ukraine and give recommendations for National Internationalization Strategy development. To achieve the above aim, several methods have been used, including internet search, analysis, systematization of evident information. The European vector for developing Ukraine has been confirmed by the accession to the Bologna Process (2005) and Association Agreement between the European Union (EU) and Ukraine (2014). Basis for higher education internationalization (Bologna instruments and legislative documents) have been analyzed. The goals and tasks of the Ukrainian State Center for International Education of the Ministry of Education and Science of Ukraine (the official state source of information on the education of foreign students in Ukraine) are presented. Statistical data from Development Strategy of the state enterprise "Ukrainian State Center for International Education for 2021-2025" prove the increase of foreign students in Ukraine. SWOT analysis of the higher education internationalization in Ukraine revealed strengths, weaknesses, opportunities and threats of higher education internationalization. The current state of higher education internationalization in Ukraine is also clarified by the results of PESTL analysis identifying Political, Economic, Social, Technological, and Legal aspects of the external environment that affect this process. It is stated that Ukraine faces the following challenges

\footnotetext{
${ }^{1}$ Doctor Habilitated in Educational Sciences, Associate Professor, Senior Researcher, Institute of Higher Education of National Academy of Educational Sciences, Ukraine 
concerning academic mobility: insufficient / no funding; non-recognition of degrees / diplomas; unsatisfactory level of foreign language proficiency; inappropriate educational programs / training organization; legal issues; lack of information and encouragement; personal problems of students. The degree of involvement of scholars and academics in international cooperation is very low. The main aspects for the National Internationalization Strategy in Ukraine and their content components are highlighted as following: worldview and value aspect (mission, vision, values, principles); organizational and resource aspect (goals and objectives, approaches, methods, tools, forms, mechanisms, organizational structure and functions, resources); regulatory and legal aspect (legislative regulation: tools for recognition, implementation of mobility, introduction of joint educational programs, mechanisms for ensuring the quality of higher education). It is recommended to develop National Internationalization Strategy; to involve foreign experts for the accreditation of Ukrainian educational programs and participate in the accreditation of foreign educational programs; to develop the Ukrainian rating of universities taking into account indicators of internationalization: foreign students; foreign academics in the Ukrainian universities; publications in foreign scientific journals; joint educational programs / research.

\section{Introduction}

In response to the demands of an ever globalizing world and motivated by a variety of academic, economic, political, and social goals [15], governments around the world are implementing policies and programs to promote higher education internationalization. Higher education internationalization has become an explicit goal for national policies, but there is a variety of approaches to this process in different countries. Not surprisingly, there is no single pattern how to internationalize higher education. But the effectiveness is affected by different issues. The most important issues are how policies are being implemented, and by whom. National policies may be implemented by involving many actors (ministries, non-governmental organizations, funds, etc.) or just a few. The Ministers responsible for higher education, meeting online on 19 November 2020, stated "we envision the European Higher Education Area (EHEA) as an area where students, staff and graduates can move freely to study, teach and do research. The EHEA 
of our vision will fully respect the fundamental values of higher education and democracy and the rule of law. To achieve our vision, we commit to building an inclusive, innovative and interconnected EHEA by 2030, able to underpin a sustainable, cohesive and peaceful Europe" [20].

The most challenging issue for effective internationalization is the level at which policies are funded, the ways in which funding is distributed, and the degree to which funding is sustained over time. So, funding is important for successful internationalization.

The current difficulties related to the COVID-19 pandemic commit to supporting higher education institutions in using digital technologies for learning, teaching and assessment, as well as for academic communication and research, and to investing in the development of digital skills and competences for all [20].

The aim of this article is to examine national policy of Ukraine for higher education internationalization, consider issues of foreign students' study in Ukraine and give recommendations for National Internationalization Strategy development.

To achieve the above aim, several methods have been used, including internet search, analysis, systematization of evident information.

\section{European vector for developing Ukraine}

On May 19, 2005, at the conference in the Norwegian city of Bergen, Ukraine officially joined the Bologna Process. The accession to the Bologna Process provided an opportunity to carry out structural transformations of higher education according to an agreed system of criteria, standards and characteristics, which allows Ukraine to become a part of the European educational and scientific area.

Association Agreement between the European Union and Ukraine (2014) confirmed the European vector for developing Ukraine. The chapter 23 "Education, training, and youth" states the aim of cooperation in the field of education, training and youth "to enhance mutual understanding, promote intercultural dialogue and increase the knowledge of their respective cultures" (Article 430); "to intensify cooperation in the field of higher education, aiming, in particular at: (a) reforming and modernizing the higher education systems; (b) promoting convergence in the field of higher education deriving from the Bologna process; 
(c) enhancing the quality and relevance of higher education; (d) stepping up cooperation between higher education institutions; (e) building up the capacity of higher education institutions; (f) increasing student and teacher mobility: attention will be paid to cooperation in the field of education with a view to facilitating access to higher education" (Article 431); "to increase the exchange of information and expertise, in order to encourage closer cooperation in the field of vocational education and training with a view, in particular, to: (a) developing systems of vocational education and training, and further professional training throughout the working life, in response to the needs of the changing labor market; (b) establishing a national framework to improve the transparency and recognition of qualifications and skills drawing, where possible, on the EU experience" (Article 432). At the same time, full respect to the responsibility of the Parties for the content of teaching and the organization of education systems and their cultural and linguistic diversity is guaranteed [13].

\section{Legislative basis for higher education internationalization}

According to the Law of Ukraine "On Higher Education" (Article 75) the main areas for international cooperation in higher education sector include:1) "participation in programs of bilateral and multilateral interstate and inter-institutional exchanges of students, graduate students, doctoral candidates, educators, academics and researchers; 2) conduction of joint research; 3) organization of international conferences, symposia, congresses and other events; 4) participation in international academic and research programs; 5) joint publishing activity; 6) provision of services related to attainment of higher education and post-diploma education by foreigners in Ukraine; 7) setting up of joint academic and research programmes with foreign higher education institutions, research institutions and organizations; 8) foreign business travel of pedagogical, academic and research staff for pedagogical, academic and research work according to Ukraine's international agreements and agreements between higher education institutions and foreign partners; 9) engagement of pedagogical, academic and research staff of foreign higher education institutions to participate in pedagogical, academic and research work in higher education institutions in Ukraine; 10) sending of persons enrolled at higher education institutions in Ukraine to study at foreign higher education institutions; 
11) promotion of academic mobility of academics, researchers and learners; 12) other areas and forms not prohibited by the law" [6].

The state policy of Ukraine in the field of higher education is based on the higher education system integration into the European Higher Education Area and the European Research Area (ERA).

The National Qualifications Framework [5], the List of Areas of Knowledge and Specialties for Higher Education Applicants [7], the Regulations on the Procedure for Exercising the Right to Academic Mobility [8], the ratified Convention on the Recognition of Qualifications concerning Higher Education in the European Region [9] constitutes the legal basis for higher education internationalization development and integration into the EHEA and ERA.

The National Qualifications Framework [5] is a systematic and competency-based description of qualification levels of education. The updated National Qualifications Framework harmonizes with the European standards and creates conditions to facilitate mutual recognition of qualifications, ensures the comparability of educational and professional qualifications acquired in Ukraine and abroad.

The Regulations on the Procedure for Exercising the Right to Academic Mobility [8] establishes the procedure for organizing academic mobility programs for participants of the educational process of domestic higher education institutions (scientific institutions) in Ukraine or abroad and participants of the educational process of foreign higher education institutions (scientific institutions) in Ukraine.

According to the place of realization of the right to academic mobility, it is divided into: internal academic mobility - the right to which is exercised by domestic participants of the educational process in the higher educational institutions (research institutions) - partners within Ukraine; international academic mobility - the right to which is exercised by domestic participants of the educational process in higher educational institutions (scientific institutions) - partners outside Ukraine, as well as foreign participants of the educational process in domestic higher educational institutions (scientific institutions) [8].

The main types of academic mobility are the following: degree mobility study in a higher education institution, different from the permanent place of study of a participant of the educational process, in order to obtain a 
higher education degree, confirmed by a document (documents) on higher education or on obtaining a higher education degree from two or more higher education institutions; credit mobility - study in a higher education institution other than the permanent place of study of a participant of the educational process, in order to obtain credits of the European Credit Transfer and Accumulation System and / or relevant competencies, learning outcomes (without obtaining credits of the European Credit Transfer and Accumulation System) recognized in a higher educational institution of a permanent place of study of a domestic or foreign participant of the educational process. At the same time, the general training period for such participants in credit mobility programs remains unchanged [8].

Training of domestic and foreign participants of the educational process on agreed between higher education institutions (research institutions) partners educational programs, including academic mobility programs, may provide graduates with a document of higher education institution (research institution) - partner, as well as joint or double documents on higher education of higher educational institutions (scientific institutions) - partners. The participants obtain degrees of junior bachelor, bachelor, master and doctor of philosophy. Forms of academic mobility for persons obtaining the degree of doctor of sciences, academics, researchers and other participants of the educational process are the following: participation in joint projects; teaching; scientific research; scientific internship; certification training.

Academics, researchers and employees of higher education institutions (scientific institutions) of all forms of ownership may exercise the right to academic mobility for professional activities in accordance with the concluded agreement on participation in the academic mobility program. At the same time, these employees retain their main place of work in a domestic higher educational institution (scientific institution) for up to one year. Remuneration in accordance with the law at the main place of work is maintained for up to six months, if it is not provided by the academic mobility program [8].

The procedure for recognition of foreign documents on education has been significantly reformed according to the Law of Ukraine "On Higher Education". Regulatory act, which controls carrying out of the recognition procedure in Ukraine by all competent authorities, is the Decree No 504 of the Ministry of Education and Science, dated on May 05, 2015. This decree 
enables Academic Technology Approved Schemes of Recognition of acquired abroad degrees of higher education and documents on secondary and vocational education [18].

Recognition of foreign educational documents in Ukraine is carried out in full concordance with the Convention on the Recognition of Qualifications concerning Higher Education in the European Region [9], which was validated by the Law of Ukraine No 1273-XIV, dated December 03, 1999, and Recommendations of the Convention along with Ukraine international agreements. Higher education institutions conduct recognition procedure in order to enroll the holder of a foreign educational document for further education and/or take on as a research or research and pedagogy employee to work at the higher education institutions. The decision of higher education institution recognition confirms right of the holder to continue education or to work at this higher education institutions. To operate the recognition procedure higher education institution is enabled to create a Recognition Board. The Ministry of Education and Science of Ukraine provides recognition procedure for employment and/or prolongation of the studying of the document holder at the territory of Ukraine. In both cases the corresponding certificates on recognition are issued [18].

National Information Centre of Academic Mobility (ENIC Ukraine) was established in 2011 by the Resolution No 924 of the Cabinet of Ministers, dated August 31, 2011 [16]. The functions of the National Information Centre of Academic Mobility are delegated to the State Enterprise "Information and Image Centre" of the Ministry of Education and Science of Ukraine. National Information Centre of Academic Mobility may grant a conclusion on the recognition, on the base of which the final decision by higher education institution will be made. The Centre also carries out admission of documents and runs recognition procedure in order to provide the Ministry with information necessary for decision making. The ENIC Ukraine Centre may provide a conclusion or reference about any stage of the recognition procedure: verify the authenticity of the educational document and status of foreign educational institution or carry out the qualification evaluation and ascertain academic and professional rights regarding foreign document on education. It also provides: information about educational system of Ukraine; handling of the requests concerning recognition of Ukrainian educational documents abroad (for government authorities, ENIC-NARIC network 
centers, recognition services for international recognition organizations, higher education institutions, embassies, employers, etc.; assistance in solution of recognition issues concerning Ukrainian documents on education and expertise assistance for equivalency establishment of foreign educational documents; electronic Apostille Register of the Ministry of Education and Science of Ukraine [18].

On September 4, 2013, at a meeting of the Government, the Resolution of the Cabinet of Ministers of Ukraine "On Amendments to the Resolution of the Cabinet of Ministers of Ukraine of November 12, 1997 № 1260” was adopted. The relevant resolution approved a sample supplement to the European diploma (Diploma Supplement). It should be noted that the European diploma supplement has been introduced in higher education institutions to fulfill Ukraine's obligations as a member of the Bologna Process. The appendix of the new model will be a mandatory document for all diplomas of higher education and printed in Ukrainian and English. The aim of the new educational document is to provide sufficient independent information to improve international transparency and fair academic and professional recognition of qualifications (diplomas, degrees, certificates, etc.) [16].

Diploma Supplement is one of the key documents of Europass a coordinated system of functioning of the job search service and place of study in European countries, as well as a single format of documents accompanying this process. The new appendix to the diploma provides an opportunity to objectively assess the qualification (degree) of education obtained by a graduate of a higher education institution. It contains expanded information on the qualifications and academic achievements of the university graduate, necessary to ensure international understanding and recognition of the diploma of higher education received by the graduate. The diploma supplement is a mandatory document in the vast majority of Bologna countries and is issued together with the diploma of higher education. Most countries without this appendix do not recognize higher education diplomas at all. From now on, the Ukrainian diploma with such an appendix will be adequately evaluated in any country of the Bologna area. The availability of the application will help increase the competitiveness and mobility of graduates of Ukrainian higher education institutions in both domestic and foreign employment markets. The Resolution of the Cabinet 
of Ministers of Ukraine "On Amendments to the Resolution of the Cabinet of Ministers of Ukraine of November 12, 1997 № 1260" on the Introduction of the Diploma Supplement entered into force on January 1, 2014 [16].

\section{Stakeholders in the higher education internationalization}

Before examining the national policy, we take stock of the variety of national government bodies and other entities that instigate and implement the higher education internationalization. Except ministries, a variety of other stakeholders also impact the development and implementation of such policies, including higher education associations, regional university networks, institutions themselves, and more broadly, students, taxpayers, and employers.

In Ukraine, the Ministry of Education and Science is the primary actor. Ukrainian State Center for International Education of the Ministry of Education and Science of Ukraine is the official state source of information on the education of foreign students in Ukraine. Ukrainian State Centre for International Education is a state owned enterprise operating in the field of international education. The Centre's activities are aimed at promoting education in Ukraine for foreigners. The enterprise was founded in Ukraine in 2002 and belongs to the Ministry of Education and Science of Ukraine.

The goal of this Centre is to help international students get internationally recognized quality education in Ukrainian universities, which will guarantee them absolute professional success in any country of the world. Development Strategy of the state enterprise "Ukrainian State Center for International Education" for 2021-2025 has been developed [14].

This Centre's tasks are the following: "provide free consultations on the conditions of admission, specifics of study and stay in Ukraine; inform about invitations for study registered by educational institutions; organizationally insure meetings of entrants by representatives of educational institutions at state border checkpoints of Ukraine; promote socio-cultural integration of foreign students in Ukraine; organize "Study in Ukraine" exhibitions abroad; ensure the work of information and telecommunication systems with the possibility of direct online interaction of foreign applicants/students and educational institutions of Ukraine; promote the implementation of the European Union's policy in the field of international education" [14]. 
The Centre provides free placement of information about Ukrainian educational institutions and services they provide to foreign students; organizes the largest event on international education in Ukraine - Ukrainian International Education Forum; informs about the policy of the Ministry of Education and Science of Ukraine in the field of providing educational services to foreigners; keeps records of agreements of business entities that have agreements with educational institutions of Ukraine on the provision of services for the recruitment of foreigners as candidates for study and publish such information on the website etc. [14].

On the website one can find complete and reliable information about study opportunities in Ukraine, educational institutions, educational programs (specialties), etc. [21].

\section{Foreign students in higher education institutions}

Notwithstanding the current difficulties related to the COVID-19 pandemic, the Ministers responsible for higher education reaffirmed the target that "at least $20 \%$ of those graduating in the EHEA should have experienced a study or training period abroad". It was also committed "to enabling all learners to acquire international and intercultural competences through internationalization of the curricula or participation in innovative international environments in their home institutions, and to experience some form of mobility, whether in physical, digitally enhanced (virtual) or blended formats" [20].

Analysis of the Concept of Virtual Internationalization of Higher Education in Ukraine, developed under the international project of the EU Tempus Program "E-internationalization for collaborative learning", suggests that the development and access to new information technologies has opened the way for active development of virtual internationalization of higher education in Ukraine. This study provides examples of virtual internationalization of higher education in Ukraine, including international webinars and web workshops, online student selection procedures, international video conferences, video lectures, video seminars, work in virtual groups on common situational tasks, participation in international professional Internet forums and social networks, pedagogical video seminars, online cooperation in the preparation of scientific articles, remote use of research and laboratory equipment, video conferences, video 
lectures by foreign teachers, use of the Internet, virtual project teams during internships in foreign organizations, student participation in international competitions, business games, video interviews with representatives of foreign organizations, etc. Modern means of communication are complemented by computer training programs such as multimedia, which replace printed texts, audio and video films [4, p. 8-9].

Despite military actions in the East, the number of foreign students in the Ukrainian higher education institutions increased from 64,066 in 2016 to 80,470 representing 158 countries in 2020. In 2019-2020 317 state higher education institutions, 108 private and 30 communal provided education to foreign students.

All statistical data are taken from Development Strategy of the state enterprise "Ukrainian State Center for International Education for 2021-2025" [14]. There are: Bachelor's and Master's degrees - 70696 (87, $85 \%)$; Preparatory course - 6949 (8,64\%); Postgraduate Education 2814 (3,50\%); Academic Mobility - 11 (0,01\%). Top 10 countries by origin are the following: India - $18429(22,90 \%)$, Morocco $-8233(10,23 \%)$, Azerbaijan - 5470 (6,80\%), Turkmenistan - 5344 (6,64\%), Nigeria 4379 (5,44\%), Turkey - 3764 (4,68\%), China - 3527 (4,38\%), Egypt 3499 (4,35\%), Israel - 2561 (3,18\%), Uzbekistan - 2027 (2,52\%), others $28,88 \%$. Top 3 regions by number of international students are the following: Kharkiv (20196, Bachelor's and Master' degrees - 17899, Preparatory course - 2297), Kyiv (17634, Bachelor's and Master' degrees - 14654, Preparatory course - 2980), Odesa (9159, Bachelor's and Master' degrees - 7053, Preparatory course - 2106). Most popular specialties among international students are the following: Medicine 26040 (32,36\%), Medical Practice 6215 (7,72\%), Dentistry 5094 (6,33\%), Management 3505 (4,36\%), Pharmacy, Industrial Pharmacy 2492 (3,10\%). Forms of education of international students are the following: full-time 86,627\%, part-time 13,335\%, evening 0,034\%, and external 0,004\%. Education levels of international students are the following: Master 50,69\%, Bachelor $35,88 \%$, Specialist 11,51\%, Junior specialist 0,99\%, PhD 0,93\%.

Development Strategy of the state enterprise "Ukrainian State Center for International Education for 2021-2025" defines seven strategic goals. They are the following: 1) "Promotion of Ukrainian education abroad. 2) Provision of informational support in organization of education of 
foreigners in educational institutions of Ukraine. 3) Development of partnerships and strengthening of international cooperation. 4) Analytical activity. 5) Participation in the formation of and organizational support for the implementation of policy of the Ministry of Education and Science of Ukraine in the field of providing educational services to foreigners. 6) Creation of a system of effective interaction with foreign graduates and their organizations in order to establish a positive image of Ukraine in the world and promote the economic interests of our country. 7) Promotion of socio-cultural adaptation of foreign students in Ukraine" [14].

Quantitative indicators of higher education internationalization in Ukraine according to the results of surveys in 183 higher education institutions in December 2019 indicate the internationalization of the educational process: number of foreign teachers in Ukrainian higher education institutions by June 2019 is 296; number of foreign applicants (bachelor) by June 2019 is 22,351; number of foreign applicants (master's degree) by June 2019 is 29,142; number of foreign entrants in $2018 / 19$ is 17,839 ; number of foreign graduates in $2018 / 19$ is 7,721 ; number of foreign partner universities by June 2019 is 5952; number of double degree programs by June 2019 is 526; the number of students who made an academic exchange in 2018/2019 academic year is 7,561; number of teachers of Ukrainian who teach in foreign universities, as of June 2019 650; number of Honorary Doctors awarded to Ukrainian teachers in foreign universities as of June 2019 122; number of awarded Honorary Doctors for foreign teachers in Ukrainian higher education institutions by June 2019 is 769; number of international projects dedicated to the quality of higher education by June 2019 is 463; number of accreditations of educational programs of Ukrainian higher education institutions by a foreign agency by June 2019 is 62 [10].

Favorable factor to increase a number of foreign students in Ukrainian higher education institutions we consider to be the Order of the President of Ukraine "On Improving Higher Education in Ukraine" from June 3, $2020(210 / 2020)$. One of the issues is to develop and approve by September 1, 2020 Action Plan to promote opportunities for foreign students to get higher education in Ukraine. This Action Plan has not been approved yet. 


\section{SWOT and PESTL analyses of the higher education internationalization in Ukraine}

To assess the state of internationalization of higher education, we have conducted a SWOT analysis, which is used in the process of strategic planning, which consists in dividing factors and phenomena into four categories: Strengths and Weaknesses; Opportunities that open up during its implementation and Threats associated with its implementation. The analysis of the state of higher education internationalization allows identifying the strengths and weaknesses of internationalization in Ukraine, opportunities and challenges.

Table 1

\section{SWOT analysis of the internationalization of higher education in Ukraine [2, p. 310].}

\begin{tabular}{|c|c|}
\hline Strengths & Weaknesses \\
\hline $\begin{array}{l}\text { - European state educational policy } \\
\text { (Ukraine-EU Association Agreement, } \\
\text { associate membership of Ukraine in the } \\
\text { EU program "Horizon 2020", strategic } \\
\text { documents); } \\
\text { - relevant educational legislation to } \\
\text { ensure the internationalization of higher } \\
\text { education; } \\
\text { - availability of state structures for } \\
\text { academic mobility and international } \\
\text { education; } \\
\text { - initiative staff of universities with } \\
\text { experience in implementing international } \\
\text { projects }\end{array}$ & $\begin{array}{l}\text { - Lack of world-class universities due } \\
\text { to non-compliance with the quality } \\
\text { parameters of world rankings; } \\
\text { - imperfect financial legislation, in } \\
\text { particular regarding the financial } \\
\text { autonomy of universities; } \\
\text { - unformed culture of quality and } \\
\text { academic integrity; } \\
\text { - unsatisfactory quality of higher } \\
\text { education; } \\
\text { - low level of English competence among } \\
\text { students, teachers and researchers; } \\
\text { - limited English-language information } \\
\text { on higher education on the Internet }\end{array}$ \\
\hline Opportunities & Threats \\
\hline $\begin{array}{l}\text { - Capacity building of higher education, } \\
\text { science, universities, people through } \\
\text { participation in EU education and } \\
\text { research programs (Erasmus }+ \text {, Horizon } \\
2020 \text { ); } \\
\text { - development of attractive educational } \\
\text { programs and international joint programs } \\
\text { for international students; } \\
\text { - "brain circulation". }\end{array}$ & $\begin{array}{l}\text { - Non-fulfillment of obligations in } \\
\text { international projects, especially as } \\
\text { a grant holder, by universities due to } \\
\text { legal financial restrictions on the use of } \\
\text { international grants; } \\
\text { - non-recognition of Ukrainian higher } \\
\text { education diplomas; } \\
\text { - invisibility of Ukrainian higher } \\
\text { education and universities in the world; } \\
\text { - "brain drain". }\end{array}$ \\
\hline
\end{tabular}


To enhance higher education internationalization Ukraine has a number of agreements with European countries and participates in the European programs.

Ukraine signed an agreement with the International Visegrad Fund, an international organization based in Bratislava, established by the governments of the Visegrad Group (V4) of the Czech Republic, Hungary, Poland and Slovakia in Stirin, Czech Republic, on June 9, 2000. The purpose of the fund is to promote development of cooperation between citizens and institutions in the region, as well as between the V4 countries and other countries, especially in the western part of the Balkan Peninsula and the Eastern Partnership. The foundation has several grant programs and also provides nominal scholarships for student mobility [12].

The US government-funded Fulbright program is at the forefront of the international education system. Based on the idea of cooperation and mutual understanding, based on knowledge and respect in a diverse world, the program has been operating successfully since 1946, now in 160 countries. During the program's existence in Ukraine since 1992, about 1,000 Ukrainians studied, did internships, and conducted research in the United States; in turn, more than 650 Americans taught in Ukrainian free economic zones and performed scientific work [3].

During the implementation of the Seventh Framework Program (2007-2013), Ukraine took a leading position among the Eastern Partnership countries and entered the top ten most active partner countries, following the United States, Canada and the BRICS countries (Brazil, Russia, India, China and South Africa). Scientific institutions and higher education institutions of Ukraine took part in 126 projects of the Seventh Framework Program with the amount of funding from the European Commission in the amount of about 26,5 million euros [1].

The EU's Horizon 2020 program (2014) is the largest transnational research and innovation program. The program's budget (about 80 billion euros) makes it one of the most expensive programs of state support for science in the world. The main objectives of the program are to support European science at the highest world level, to remove obstacles to innovation and to enable cooperation between the public and private sectors in order to conduct joint research and create innovative products. 
It should be noted that during 2014, 24 projects with the participation of Ukrainian institutions won and began to receive funding. Ukraine was among the 10 most active participants, then still among the third countries. On March 20, 2015, the Agreement between Ukraine and the European Union on Ukraine's participation in the EU Framework Program for Research and Innovation "Horizon 2020" was signed, which has a number of differences from the Seventh Framework Program and should be taken into account when preparing project proposals [1].

The current state of higher education internationalization in Ukraine is also clarified by the results of PESTL analysis. PESTL analysis is a marketing tool designed to identify Political, Economic, Social, Technological, and Legal aspects of the external environment that affect the company's business. So, according to the author's study [2, p. 303] there have been clarified the following: political aspects: Ukraine - EU Association Agreement, Ukraine's participation in international organizations and programs; favorable visa regime; absence of strategy for the internationalization of higher education in Ukraine, in particular in terms of creating and improving the image of domestic higher education, the uncertain role of the media; availability of the National Information Center for Academic Mobility (ENIC) and the Ukrainian State Center for International Education of the Ministry of Education and Science of Ukraine; economic aspects: expenses on higher education make up a percentage of GDP at the level of developed countries, but scattered, but expenses on research are much lower; the pricing policy of the market of educational services is favorable for attracting foreign students; social aspects: changes in basic values in the context of European integration; negative demographic changes; a large number of higher education institutions that meet the demand for higher education; introduction of educational programs, courses in foreign languages; availability of support and adaptation programs for foreign students; technological aspects: availability of free resources based on information and communication technologies for creating a virtual educational environment and conducting electronic courses; use of information and communication technologies for international marketing of the Ukrainian higher education; legal aspects: modernized educational legislation in accordance with the provisions of the Bologna process; normative and legal documents regulating international economic activity 
in higher education need to be harmonized with international documents, first of all with the EU - Ukraine Association Agreement.

In the world of globalized higher education, international university rankings are becoming increasingly relevant for applicants to find out which university to enter in a foreign country, and for the universities themselves in order to attract foreign students, grants and investments, the best teachers and researchers due to high positions (or the fact of inclusion in the ranking). Thus, the position of the university in the rankings is a tool for assessing the quality of higher education.

Ukrainian universities in the international rankings QS World University Rankings (2019) are the following: V.N. Karazin Kharkiv National University, Taras Shevchenko National University, KPI National Technical University, Kharkiv Polytechnic Institute National Technical University, Sumy State University, Lviv Polytechnic National University; in Times Higher Education (2020) the following universities are represented: Lviv Polytechnic National University, Ivan Franko National University, Kharkiv Polytechnic National University, Sumy State University, Taras Shevchenko National University, V.N. Karazin Kharkiv National University. The largest number of Ukrainian universities is represented in the Webometrics rating (2019) [19; 22]. So, only few Ukrainian universities are visible in the ratings and none of them is in the Academic Rating of World Universities.

At the same time it should be mentioned that education in Ukraine is a sector often perceived to be marked by corruption. According to the results of a 2013 survey conducted by Razumkov Centre, state authorities in general and judiciary and law enforcement agencies in particular are widely believed to be very corrupt. Among public services, respondents believe that corruption is pervasive or widespread in health $(85 \%)$, higher education $(77 \%)$ and secondary education (53\%) [17, p. 14]. Thus, to attract more foreign students to the Ukrainian higher education institutions it is necessary to overcome corruption and enhance quality of education.

Based on the results of the study of world experience, the conceptual principles for higher education internationalization in Ukraine have been developed, taking into account the trends and features of higher education internationalization in the global, regional and national dimensions. The main aspects for the National Internationalization Strategy in Ukraine and their content components are highlighted as following [2, p. 311]: worldview 
and value aspect (mission, vision, values, principles); organizational and resource aspect (goals and objectives, approaches, methods, tools, forms, mechanisms, organizational structure and functions, resources); regulatory and legal aspect (legislative regulation: tools for recognition, implementation of mobility, introduction of joint educational programs, mechanisms for ensuring the quality of higher education).

It is noted that the higher education internationalization in Ukraine should be based on a system of principles: social and national orientation; openness and transparency; economic feasibility; scientific validity; on student-centered and competency-based approaches; on intercultural and civic values.

National features and traditions in the international activity and higher education internationalization determine the expediency of gradual transformations depending on the speed and quality of contextual transformations in the higher education system. Therefore, it is important for Ukraine to develop National Internationalization Strategy, which will present an appropriate system of principles, approaches, methods and a set of actions and directions of educational, research, administrative activities through which the mission and vision of higher education internationalization is being realized, long-term goals of socio-humanitarian, political, economic, academic development of higher education in the global and regional dimensions are being achieved. We can offer practical recommendations for internationalization at the national level, in particular at the following levels [2, p. 329]: legislative: development of state programs for study abroad in priority areas; regulation in employment of academic staff from foreign countries; development of recognition tools, in particular learning outcomes within academic mobility; mechanisms for implementing mobility; introduction of joint educational programs of double diplomas / degrees, in particular English ones; mechanisms for ensuring the quality of higher education based on international standards; new approaches to the financing of higher education and research, to the economic activity of higher education institutions in general; national ranking of universities with the internationalization indicators; improving the legal framework for the education of foreign students; organizational and administrative: development of academic mobility services in higher education institutions, aiming at organization of mobility, ensuring the recognition of learning 
outcomes; international offices for academic mobility; organizational and methodological: involvement of higher education institutions in the national and international rankings through financial and economic incentives; introduction of English-language educational programs; educational research: development of centers of excellence in competitive research areas to attract foreign experts and doctoral students to joint research.

\section{Conclusions}

Internationalization has become a subject of global interest and global geographical coverage. In order to develop a National Internationalization Strategy of Ukraine, it is necessary to take into account trends and patterns in the global market of international educational services: a) increase the number of institutions providing cross-border education and the emergence of new participants in the market of educational services; b) commercialization of educational services; c) commodification of higher education; d) global competition for the involvement of students and professionals; e) regional features of internationalization; f) taking into account the local context and cultural characteristics when involved in global cross-border processes; g) internationalization of scientific research. Global interpretations of internationalization require a more careful approach to its implementation in practice than has been the case until recently.

The implementation of an effective model of internationalization requires modernization of the legal framework for the internationalization of educational, scientific and scientific-technical activities. In particular, legislative regulation is needed in: recognition instruments (National Qualifications Framework; Diploma Supplement; European Credit Transfer System); academic mobility regulations; mechanisms for implementing mobility (social security for mobility participants e.g. saving salaries / scholarships, pension contributions, social insurance for the period of mobility; employment of foreign applicants for higher education); introduction and accreditation of joint educational programs of double diplomas / degrees, in particular English ones; higher education quality assurance mechanisms based on international standards (membership of the National Agency for Quality Assurance in Higher Education in the European Register of Quality Assurance in Higher Education); research 
projects; economic activity of higher education institutions; creation of a national ranking of universities.

It is recommended to develop a National Internationalization Strategy; to involve foreign experts in the accreditation of Ukrainian educational programs and participate in the accreditation of foreign educational programs; to develop the Ukrainian rating of universities taking into account indicators of internationalization: foreign students; foreign academics in the Ukrainian universities; publications in foreign scientific journals; joint educational programs / research.

At the same time, Ukraine faces the following challenges concerning academic mobility: insufficient / no funding; non-recognition of degrees / diplomas; unsatisfactory level of foreign language proficiency; inappropriate educational programs / training organization; legal issues; lack of information and encouragement; personal problems of students.

The degree of involvement of scholars and academics in international cooperation is very low, the small share of those who studied or worked abroad, as well as the small number of holders of foreign scientific degrees. Ukraine has long been a country that mainly exports highly qualified staff and talented youth.

\section{References:}

1. Horyzont 2020 [Horizon 2020]: URL: https://www.kmu.gov.ua/ua/ diyalnist/yevropejska-integraciya/programi-ta-agentstva-yes/gorizont-2020 (accessed 10 February 2021).

2. Debych M.A. (2017) Internatsionalizatsiia vyshchoi osvity: svitovyi dosvid [Internationalization of higher education: world experience]: monohrafiia. Sumy: Universytetska knyha (accessed 10 February 2021).

3. Istoriia prohramy Fulbraita [Fulbright Program History]. URL: http://www.fulbright.org.ua/uk/pages/17/program-history.html (accessed 10 February 2021).

4. Kontseptsiia virtualnoi Internatsionalizatsii vyshchoi osvity Ukrainy [The concept of virtual internationalization of higher education in Ukraine]. URL: http://eicl.kharkiv.edu/upload/E-internationalization\%20concept_Ukraine. pdf (accessed 10 February 2021).

5. Natsionalna ramka Ukrainy [National Framework of Ukraine]: Dodatok do postanovy Kabinetu Ministriv Ukrainy vid 23 kvitnia 2011 r. № 1341. URL: https://zakon.rada.gov.ua/laws/show/1341-2011-\%D0\%BF/paran12\#n12 (accessed 10 February 2021).

6. Pro vyshchu osvitu: Zakon Ukrainy vid 01.07.2014 r. № 1556-VII. Data onovlennia: 28.09.2017. [Law of Ukraine "On Higher Education"]. 
URL: https://zakon.rada.gov.ua/laws/show/1556-18.\#Text (accessed 10 February 2021$)$.

7. Pro zatverdzhennia pereliku haluzei znan i spetsialnostei, za yakymy zdiisniuietsia pidhotovka zdobyvachiv vyshchoi osvity [On the statement of the list of branches of knowledge and specialties on which preparation of applicants of higher education is carried out] (2015): Postanova Kabinetu Ministriv vid 29 kvitnia 2015 r. № 266. URL: https://www.kmu.gov.ua/npas/248149695 (accessed 10 February 2021).

8. Pro zatverdzhennia Polozhennia pro poriadok realizatsii prava na akademichnu mobilnist [Regulations on the procedure for exercising the right to academic mobility] (2015): Postanova Kabinetu Ministriv vid 12 serpnia 2015 r. № 579. URL: https://zakon.rada.gov.ua/laws/show/579-2015-\%D0\%BF\#Text (accessed 10 February 2021).

9. Pro ratyfikatsiiu Konventsii pro vyznannia kvalifikatsii z vyshchoi osvity v Yevropeiskomu rehioni [On ratification of the Convention on the Recognition of Qualifications concerning Higher Education in the European Region]. Lisabon, 11 kvitnia 1997 roku. URL: https://zakon.rada.gov.ua/laws/show/994_308\#Text (accessed 10 February 2021).

10. Richnyi zvit Natsionalnoho ahentstva iz zabezpechennia yakosti vyshchoi osvity za 2019 [Annual report of the National Agency for Quality Assurance in Higher Education for 2019] / za zah. red. Prof. Cerhiia Kvita. Kyiv: Natsionalne ahentstvo iz zabezpechennia yakosti vyshchoi osvity, 2020. 244 p. URL: https://naqa.gov.ua/wp-content/uploads/2020/02/\%D0\%97\%D0\%B2\%D1\% 96\%D1\%82-2020.pdf. C. 95. (accessed 15 February 2021).

11. Shest ukrainskikh vuzov voshli v reiting luchshikh v mire: stali izvestny podrobnosti [Six Ukrainian universities entered the ranking of the best in the world: details became known]. URL: https://theworldnews.net/ua-news/shest-ukrainskikhvuzov-voshli-v-reiting-luchshikh-v-mire-stali-izvestny-podrobnosti (accessed 15 February 2021).

12. About the Visegrad Group. URL: http://www.visegradgroup.eu/about (accessed 15 February 2021).

13. Association Agreement between the European Union and Ukraine. URL: https://www.kmu.gov.ua/storage/app/media/uploaded-files/TITLE\%20V.pdf (accessed 15 February 2021).

14. Development Strategy of the state enterprise "Ukrainian State Center for International Education" for 2021-2025. Kyiv, 2020. 48 p. URL: https://studyinukraine.gov.ua/en/development-strategy-of-the-state-enterpriseukrainian-state-center-for-international-education-for-2021-2025/(accessed 15 February 2021).

15. de Wit, H. (1999) Changing Rationales for the Internationalization of Higher Education. International Higher Education. URL: https://www.researchgate.net/ publication/313407781_Changing_Rationales_for_the_Internationalization_of Higher_Education (accessed 15 February 2021).

16. National Tempus / Erasmus+ Office in Ukraine. Zatverdzheno zrazok dodatku do diploma yevropeiskoho zrazka [The sample of the appendix to 
the diploma of the European sample is approved] (Diploma Supplement). URL: http://www.tempus.org.ua/en/vyshha-osvita-ta-bolonskyj-proces/informacijnoanalitychni-materialy/1015-zatverdzheno-zrazok-dodatku-do-diploma-jevropejskogo-zrazka-diploma-supplement-.html (accessed 15 February 2021).

17. OECD (2017), OECD Reviews of Integrity in Education: Ukraine 2017, OECD Publishing, Paris 190 p. URL: http://dx.doi.org/10.1787/9789264270664) (accessed 15 February 2021).

18. Policies and procedures for the recognition of qualifications. URL: https://www.enic-naric.net/ukraine.aspx\#anc01 52 (accessed 15 February 2021).

19. QS Results. Ukraine. URL: https://www.universityrankings.ch/en/results/ QS/2019? ranking $=$ QS\&year $=2019$ \&region $=\& q=$ Ukraine $($ accessed 15 February 2021).

20. Rome Ministerial Communiqué (2020). URL: https://ehea2020rome.it/ storage/uploads/5d29d1cd-4616-4dfe-a2af-29140a02ec09/BFUG_Final_Draft_ Rome Communique-link.pdf (accessed 15 February 2021).

21. Study in Ukraine. URL: https://studyinukraine.gov.ua/ (accessed 15 February 2021).

22. Webometrics - 2019: Internet reitynh ukrainskykh vyshiv [Internet rating of Ukrainian universities]. URL: https://osvita.ua/vnz/rating/65258/ (accessed 15 February 2021). 